Discourse and Communication for Sustainable Education, vol. 7, no. 2, pp. 43-51, 2016

\title{
Philosophy of Sustainable Development, Polish Perspective
}

\author{
Tomasz Zygmunt \\ State School of Higher Education, Poland
}

\begin{abstract}
The aim of the present paper is to awake awareness of the term "sustainable development" and show that the very term is not understood in a unilateral way. A discrepancy of perception and thus understanding of the notion of sustainability blurs its meaning. Numerous scholars and researchers use the term sustainable or sustainability to refer to the area where abilities of using methods to prevent natural resources can be demonstrated. Besides, scholars and researchers, especially in Central Europe, approach sustainability in a holistic way, paying more attention to a doer (subject) than to the doer's vicinity full of natural resources (objects). Also school teachers in Poland, when given a task to explain the meaning of sustainable development, tend to underscore personal, social and intellectuals' abilities and skills of people. The teachers' observations served as catalysts to develop the presented in the paper discussion and conclusions.
\end{abstract}

Keywords: sustainable development, philosophy of life, education, humanity, semantic field, social milieu

\section{Introduction}

Every human activity, being different from a non-human one, is marked by a conscious approach to a pre-planned task and full awareness of the process of implementing the task requirements, foreseeing, at the same time, its final results. Due to individual differences between human beings, it is quite probable that one and the same task given to two individuals can be substantiated in two different ways thus, resulting in two different outcomes. Not only are age, experience or skills responsible for the final image of substantial or insubstantial value of human activity. Before turning any idea, plan or intention into reality, it is strongly desirable for the doer to perceive and comprehend all those intricacies which he can come across on the way to the designed destination. Besides, it has to be remembered that ideas or plans become very demanding and perplexed when the final outcome of carefully designed and conscious actions is to be human development of any nature. Out of many developmental aspects, sustainable development of a single human being seems to be of paramount importance for a harmonious and safe functioning of humanity. 
Whenever sustainable development becomes a subject matter of discussion, it gives rise to queries and controversies as the issue of sustainability is differently perceived by different social communities in different countries. This is so because the very term sustainability - is manifested in an array of meanings and interpretations, depending on the needs of its application to reach goals either of social and practical, on the one hand, or purely academic nature, on the other. Therefore, the task of the present discussion is to attempt to penetrate and clarify the notion of sustainability as it is perceived and understood by some circles in Poland.

\section{Philosophy of Sustainability}

Generally speaking, the notion of sustainability, as it appears in the language of Polish academics, is not monolithic. First of all, it has to be stressed that scholars representing sciences, especially the earth sciences or the modern sciences of ecology, stress the practical aspect of sustainability and thus, understand it differently from those who represent the humanities and view sustainability through the prism of its non-material values. Moreover, the understanding of the very term has much to do with the influence of English from where the term was adopted to Polish via translation. But the Polish equivalents, to a certain extent, blur the true meaning of the term, and thus, cause controversies. To exemplify the present discussion, let us have a look at the semantic field composed by the equivalents of the verb sustain. In Polish, the verb sustain, as it appears in English - Polish dictionaries, directs our attention to the spheres of activities denoted by the following verbs: suspend - maintain - carry - hold - supply - withstand - experience - claim - affirm - suffer - perform - continue - extend (Bulas \& Whitefield, 1967; Stanisławski, 1980). Very rarely, is "sustainability" explained shortly as related to support. As a matter of fact, a vast majority of dictionaries, including encyclopedic dictionaries, do not even give such an entry as "sustainability". Instead, they only include "sustainable", explaining it as capable of being sustained or maintained (Webster's New Universal..., 1983). Finally, "sustained" is defined as "maintained at length without interruption, weakening or losing in power or quality" (Webster's Third..., 1993, p. 2304).

The content of the presented above semantic field and its clash with the commonly used meaning of the word "sustainability" derived from the field, points to the quality of translation as responsible for the correct or incorrect use of any word, since translatability makes us sensitive to the understanding of the very thought or idea embedded in the translated word (cf. Zygmunt, 2016). Hence, the multitude of Polish equivalents to the English verb "sustain" must have resulted in multiple versions denoting sustainability, in many cases deviating from its core meaning. As mentioned earlier, representatives of exact sciences or natural science view sustainability as a factor applicable for practical reasons in the sphere of ecology or economics while the humanity minded academics pay more attention to spiritual or intellectual values to become elements of sustainable development of Man, perceived holistically (cf. Salite, 2015). At this point we witness two philosophical trends which can be applicable in the process of human development, in general.

One may object to the employment of philosophy and the philosophical approach to the very understanding of sustainability. Without a doubt and reservation it can be claimed that sustainability or sustainable development is directly related to social philosophy and the philosophy of life in its milder form, known in German as Labensphilosophie, 
which in one way or the other forges a way to accomplishing the designed plans, and thus success in human life.

To understand the above mentioned relationship we have to understand and accept the role played in human life by philosophy, in general. The role assigned to philosophy becomes transparent when we only understand its true nature. The term "philosophy" is composed of two Greek words: filein, meaning to love, and sofia which means wisdom. Hence, philosophy means "the love for wisdom". Undoubtedly, wisdom is the sense of human life which can be perfectly shaped due to the human strive for development of any nature, including sustainable. In this respect, philosophy of life in its pragmatic manifestation, especially this one represented by William James (1995) gives indications for human development.

According to James's view, the world we create through our daily activities is a cluster of diverse experiences that can only be understood through a proper application of methods springing up from empiricism. Hence, this empiric view clearly shows that our knowledge derives from experience. Since the consequence of human development is both the development and deepening of knowledge, and since knowledge derives from experience, this sets a staged process of gaining experience which is responsible for harmonious and sustainable development. Nevertheless, it has to be taken into account that empiricism does not ignore the power of mind of the involved in human activity doer, and his acts of observation but considers them as vital for the final outcome of any empirical approach. Moreover, an active human being - doer - is not fostered in isolation but in a social milieu and in a given social situation. Hence, James stresses that people change and develop how they act. Thus the development of an active individual will be directly related to the role he actually plays in the social environment. At this point we can risk assuming that if you are "great", the social environment will help you develop your greatness (James, 1956; 1995).

Far more influential in developing and shaping human personality is social philosophy and also, although lesser in scope and effect, philosophy of dialog represented by Buber (2002) and Ebner (in Green, 1980) who emphasize the role of relationship between human beings linked by a direct contact enabling them communication and thought exchange. Undoubtedly, such relationship greatly contributes to human development (see also Zygmunt, 2016).

Concentrating our attention on the role of social philosophy in the process of sustainable development of a person, first of all, we have to admit that this is the human being who is responsible for whatever happens in the social environment. Again, this is the human being who is responsible for birth control and thus, increase or decrease of birthrate. Moreover, urban or rural communities need to be adapted to the environment and therefore, consume a variety of survival resources such as, for example, useful lands and waters, oil or coal that can be used to facilitate the life of communities and increase their wealth. Inevitably, the process of making use of natural resources is directly related to consumption. In consequence, the consumed resources and resources-related by-products have to be dumped as consumption always results in the waste and necessity of its storage or wipeout. At this point we need human understanding of the problem of environmental protection directly related to human behavior and daily activities, often thoughtless, causing waste heat or water wastes. Paradoxically enough, environmental protection dwells in the human mind and the human ability to perceive the source of danger. 
Viewing resources as a reserve supply that can be drawn upon when needed we often forget that resources can be also perceived as all the money, property or skills that you have available when you call for them. In this respect, we can talk about financial resources, technical resources or intellectual, inner resources pertaining to personal qualities. Undoubtedly, intellectual abilities of community members and their full understanding of the essence of sustainability is a guarantee of the world's safety and human development. Ignorant and thoughtless communities are unaware of menace resulting from human improper behavior in environmental and economic spheres of sustainability. This is so because unawareness is a source of destruction which hampers sustainable development. In many cases people behave and react unintentionally but destructively as they have never been taught what is right and what is wrong. Therefore, conditio sine qua non of sustainable development is the holistic development of a person regarded as the key element of the social sphere of sustainability. Only education with regard to the philosophy of life can give guidance to humanity pointing both to environmental threats and ways of their avoidance. The world can only be saved by conscious and thoughtful people understanding their role in its development and protection. This is the indication to what philosophy of sustainability should refer.

As mentioned earlier, sustainability and especially the notion of sustainable development is perceived in diverse ways in Poland, depending on the social and professional group of perceivers. What is important in this case, is the perception and understanding as demonstrated by school teachers as formal education for sustainable development usually starts there. For this reason a brief research was designed to examine teachers in selected schools of the Lublin School District.

\section{Interview}

In order to check the level of understanding of the term "sustainable development", a brief research in the form of interview was carried out with 47 school teachers of random choice, representing 19 schools (ranging from elementary to high school level) of the Lublin School District. The teachers were given only one simple question: What do you understand by sustainable development? (sustainable development means, in Polish, zrównoważony rozwój), and asked to write in Polish an answer in one, maximum in two sentences.

A careful analysis of the received answers allows for categorization and arranging them into 6 classes, as follows:

- Development of mental qualities and communicative skills $(\mathrm{A}=16)$

- Holistic development of a person $(B=11)$

- Harmonious deepening of knowledge, combining theory and practice $(\mathrm{C}=7)$

- Development of cooperative abilities/social skills $(\mathrm{D}=6)$

- Ability to function in a social/professional environment $(\mathrm{E}=4)$

- Ability to be sensitive or protective to the environment $(\mathrm{F}=3)$.

The capitals and digits in the brackets show the number of answers assigned to each distinguished category.

A thorough analysis of the above mentioned categories permits to combine them thematically and logically in order to distinguish two groups - one characteristic of the dominance of intrinsic features of human development $(\mathrm{A}, \mathrm{B}, \mathrm{C})$, and the other one, where extrinsic features prevail $(\mathrm{D}, \mathrm{E}, \mathrm{F})$. None of the groups is purely extrinsic or 
intrinsic. Anyway, the decision of forming such groups as above was made only on the basis of a sheer predominance of features found in the analyzed answers.

Therefore, as far as Category A is concerned (Development of mental qualities and communicative skills - 16 answers), the subjects stressed the importance of intellectual development and ability to gain and share knowledge in a formal and informal way. Besides, the knowledge of foreign languages and ability to gain and share knowledge due to international contacts (for example, exchange programs) was mentioned, as well.

Category B (Holistic development of a person - 11 answers) was hard to decide as the answers were very general, pointing to nomen omen general or holistic development. In two cases, the ability to demonstrate general knowledge for functional purposes was underscored.

Category C (Harmonious deepening of knowledge, combining theory and practice 7 cases), to some extent, is close to Category B as the reference to functional purposes can be found in both categories. However, the focus on combining theory with practice is seen in all the respondents' answers; they also emphasize the value of harmonious development of the whole person.

With reference to Category D (Development of cooperative abilities - 6 cases), it is quite evident that social skills are in focus. In all the answers, the ability to cooperate with partners and function in a social milieu was viewed as priority.

A certain resemblance can be found between Categories D and E (Ability to function in a social/professional group - 4 answers) where the respondents always put stress on functioning either in a social or professional group. No doubt, such functioning can be considered as both social and cooperative in character.

Finally, Category F (Ability to be sensitive or protective to the environment -3 answers, only) is a clear manifestation of interest in extrinsic matters related to sustainable development.

The table below gives a pure illustration of the examined teachers' understanding of sustainable development and presents their visions in the frequency of occurrence and percentage.

Table 1

School Teachers' Perception of Sustainable Development in the Frequency of Occurrence and Percentage

\begin{tabular}{cccc}
\hline \multicolumn{5}{c}{ What do you understand by sustainable development? } \\
\hline Category & Frequency & Percent & Total \\
\hline A & 16 & 34.04 & 47 \\
\hline B & 11 & 23.41 & 47 \\
\hline C & 7 & 14.89 & 47 \\
\hline D & 6 & 12.77 & 47 \\
\hline E & 4 & 8.51 & 47 \\
\hline F & 3 & 6.38 & 47 \\
\hline
\end{tabular}

It is quite significant that a vast majority of the examined teachers pointed to intrinsic factors as responsible for the process of human development. Although, as mentioned earlier, a clear division into answers either intrinsically or extrinsically inclined is difficult to determine, there is a great resemblance between the answers under Category 
$\mathrm{A}, \mathrm{B}$, and $\mathrm{C}$ in comparison to another resemblance between the answers classified as Category D, E, and F. If we only accept that the answers under A, B and C are of the intrinsic nature while the responses classifies as D, E and F are extrinsically related, we can easily observe that the image of sustainable development as created by the selected Polish school teachers strongly relies on intrinsic elements attributed to Man. Out of 47 responses, the answers considered as intrinsic in nature amount to 34 (72.34\%), which in comparison to 13 answers $(27.66 \%)$ characteristic of extrinsic inclination, puts up a hallmark pointing to the examined teachers' understanding of sustainable development. The obtained results show that a vast majority of the subjects associate sustainable development with intrinsically related factors and consider it as the very essence of human being.

As comes out from the above presented discussion, development in general is attributed to human development inseparable from the development of mental qualities and communicative skills and therefore, holistic development of a person $(27$ subjects $=$ $57.45 \%$ ). Social and functional qualities are stressed by those subjects who underscore cooperation and the development of those skills and abilities which allow for professional functioning in a social milieu ( 10 opinions $=21.28 \%$ ). Quite naturally, overconcentration on the development of human being must have resulted in a marginal treatment of sustainable development in relation to the environment ( 3 responses only $=6.38 \%$ ).

\section{Discussion}

The above-presented results resemble, at least to some extent, the observations by Switała (2015), who also points to the fact that the understanding of the concept of sustainable development varies among Polish teachers, being "intuitive rather than based on scientific or theoretical knowledge" (p. 129). The interview results clearly show that the examined teachers usually viewed sustainable development through the prism of intrinsic values directly related to the development of knowledge and mental qualities, and therefore - to the holistic development of Man (c.f. Category A, B and C). Therefore, intrinsic in nature values "which form the foundations of moral education and help us to get to know both ourselves and others better", as Świtała $(2015$, p. 125) notices, could influence the teachers' image and perception of sustainable development. Although in minority (c.f. Category D and $\mathrm{E}=21.28 \%$ ), they also find cooperative abilities and the functioning in a social or professional environment as a great asset enabling human development. Totally, an overwhelming number of responses ( $44=93.62 \%)$ underscores the need for holistic development and thus, the examined teachers identify sustainable development with the development of such features as behavioral, temperamental, emotional and especially mental that characterize a unique individual. In this respect, reflections and indications which can be worked out on the basis of the obtained during the interview data parallel the observations and opinions expressed by Salite (2015), Świtała (2015), Badjanova \& Iliško (2015) who also perceive the holistic approach to education and intrinsic values, in general, as attributes en route to sustainable development.

Yet, extrinsic matters directly related to sustainable development focused on environmental protection were present in the research results, although in a scanty count $(6.38 \%)$. It can be expected that a relatively low count may result from the lack of environmental literacy and sensitivity to environmental care and protection, which is a deficit in teachers' 
competence found not only in Poland but in Central Europe, in general (c.f. Šimonova and Činčera, 2016).

Nevertheless, it can also be expected that not only the lack of environmental literacy and sensitivity to environmental protection might have influenced the teachers' point of view and understanding of sustainability. It is very probable that the main reason of perceiving and identifying sustainable development with the development of human being was the translation of the very phrase from English into Polish. Hence, the term "sustainable development" appears in the Polish writing devoted to sustainability as “zrównoważony rozwój” where "rozwój” means development, and the meaning does not cause any problem in understanding the word's usage. The problem is caused by the used in Polish word "zrównoważony" which, as an adjective, defines the sphere of harmony and balance. In consequence, sustainable development is, first of all, understood as harmonious or balanced development. No wonder then, that bearing in mind the term "zrównoważony", the examined teachers concentrated their attention on harmonious and balanced development of a person.

Although the term development (in Polish "rozwój”) seems to be clear, yet it deserves deeper consideration. Fundamentally, development is understood as irreversible, harmonious, and well-balanced sequence of structural and functional changes dependent on both internal and external factors responsible for achieving the acme in the case of the individual or a social group. Moreover, the very term such as "life span development" as used in pedagogy, directly points to the core element of attainment and development, that is the human being. Even though there is some divergence in defining development, resulting in sub-categories such as linear development, socio-dynamic, or transformational development, all of them concentrate on Man as the subject. Hence, this is the subject WHO develops and WHOSE development exerts a powerful influence upon the development of the subject's vicinity. Yet, this is the subject whose sustainable development is directly related to the sustainable development of the Universe. What counts here is the intellectual development of a person and his understanding and sensitivity to the environmental threats. This is how the internal development, through the external functioning of the developed subject, causes that the objects which compose the environment can be protected and saved for generations.

Of great significance and value for the understanding of the notion of sustainable development is Urie Bronfenbrenner's ecological systems theory also known as the Human Ecology Theory (Bronfenbrenner, 1979). According to the theory, human development is influenced by the different types of environmental systems. These systems are composed of the micro system (that is the direct environment we live in), the mesosystem (relationships between the micro systems in the individual's life), the exosystem (social relationship evoked by human activity or the lack of activity), the macro system (cultural setting), and finally, the chronosystem (transitions and shifts in the individual's lifespan). This theory helps us understand how strongly we are related to the environment by shaping it, thus shaping simultaneously our behavior, too. Through the shaping of our behavior, we develop. This is the point which Urie Bronfenbrenner raises in his further studies where he discusses the ecology of human development (Bronfenbrenner, 2005). Human balanced development attained in the environmental setting guarantees our sensitivity to the environmental systems. This is so because the whole process of human development is shaped by the interaction between an individual and the environment. Hence, this is the essence of sustainable development. 
As a matter of fact, the presented by Bronfenbrenner point of view finds resemblance in the examined teachers' perception of sustainable development. They also stress the human aspect of sustainable development by viewing a human being as a spiritus movens of sustainability.

\section{Conclusions}

First of all, sustainable development viewed from the Polish perspective refers to the development of Man. If the intention is to develop the contemporary world, in general or the environment we live in, in particular, the starting point is the development of humankind - all people who create the environment and foster it.

It could not be risky to say that in the eyes of the examined Polish teachers' sustainable development is viewed as a holistic process that effects a single human being, which, in turn, seems to be of paramount importance for a harmonious and safe functioning of humanity. Moreover, balanced and harmonious development of human features indispensable for functioning in the environment of any nature is essential for attaining high social status. It can be expected that with this indication in mind, the majority of the subjects tried to characterize sustainable development, stressing unintentionally the validity of the holistic approach.

It cannot be denied that the development of humanity relies on the development of each individual composing it. It cannot be also denied that a fully developed individual becomes the subject who controls and exerts influence upon the objects found in the vicinity. Only then, can we say that the environment is safe and protected when it remains under maintenance and surveillance of the fully developed subject.

According to philosophy of life (Lebensphilosophie), human activity determines the level of human knowledge and perception of the outer world. Life is dynamic because human activity is dynamic but an active individual is required to be aware of the results of his or her specific behavior and actions (c.f. James, 1995). Also social philosophy and philosophy of right concentrate both on human activity within a social community and a human being as an active element of the Universe. Hence, every social group is perceived as a structured institution which serves its members to develop (c.f. Murphy, 1994).

Unfortunately, we often ignore the human being in the discussion on sustainable development turning our attention to non-human spheres of sustainability, especially economic and environmental. No sphere can develop without the development of a human being. It is strongly believed that philosophy of sustainable development can change the perspective with regard to real-sense development, showing clearly the role of a person in it. This is philosophy of sustainable development which puts the human being into the center of attention and esteem. Therefore, a person becomes the subject while the environment is treated as the object of the Universe. This is a person who evolves through the process of changes while functioning in the environment thus, effecting it and protecting due to his developed awareness and understanding of the need for saving the world. 


\section{References}

Badjanova, J. \& Iliško, Dz. (2015). Holistic approach as viewed by the basic school teachers in Latvia. Discourse and Communication for Sustainable Education, 6(1), 132-140, ISSN 2255-7547, DOI: 10.1515/dcse-2015-0010

Bronfenbrenner, U. (1979). The ecology of human development: Experiments by nature and design. Cambridge, MA: Harvard University Press.

Bronfenbrenner, U. (2005). Making human beings human: Bio ecological perspectives on human development. Thousand Oaks: Sage Publishers.

Buber, M. (2002). Between man and man. London/New York: Routledge.

Bulas, K. \& Whitefield, F.J. (1967). The Kościuszko Foundation Dictionary: English Polish, 1. New York: The Kościuszko Foundation.

Green, H.J. (1980). The word and the spiritual realities. In H.J. Green (Ed.), The word and the spiritual realities: A translation of and critical introduction to Ferdinand Ebner's Das Wort und die Geistigen Realitäten and a Comparison with Martin Buber's Ich und Du. Evanston, IL: Northwestern University.

James, W. (1995). Pragmatism. New York: Dover Publications.

James, W. (1956). The will to believe and other essays in popular philosophy and human immortality. New York: Dover Publications.

Murphy, J.G. (1994). Kant: The philosophy of right. Macon, GA: Mercer University Press.

Salite, I. (2015). Searching for sustainability in teacher education and educational research: experiences from the Baltic and Black Sea Circle Consortium for Educational Research. Discourse and Communication for Sustainable Development, 6, 21-29.

Stanisławski, J. (1980). The Great English - Polish Dictionary, 4. Warszawa: W.P.

Šimonova, P. \& Činčera, J. (2016). Do environmental education school coordinators have a mission? Discourse and Communication for Sustainable Education, 7, 23-36.

Świtała, E. (2015). Teachers' values related to sustainable development in Polish and Latvian secondary schools. Discourse and Communication for Sustainable Development, 6, 127-131.

Webster's New Universal Unabridged Dictionary. (1983). Cleveland, OH: Dorset \& Barber.

Webster's Third International Dictionary. (1993). Cologne: Koenemann.

Zygmunt, T. (2016). Language education for sustainable development. Discourse and Communication for Sustainable Education, 7, 112-124.

Correspondence concerning this paper should be addressed to Dr. Tomasz Zygmunt, Email: tomzyg@pwsz.chelm.pl or tomzygmunt@gmail.com 